\title{
Concept of costs management with environmental protection functions
}

\author{
Larisa Gerasimova ${ }^{1, *}$ and Dmitriy Silka ${ }^{1}$ \\ ${ }^{1}$ Moscow State University of Civil Engineering (National Research University) (MGSU)
}

\begin{abstract}
The article analyzes a number of possible negative factors arising in the process of realization of environmental and economic risks associated with violations of environmental legislation. The main directions of the cost of environmental activities are determined. The functional groups of expenses of an ecological orientation are allocated and characterized. Developed methodology for the functional and process accounting of environmental protection costs allowed identification of costs by the processes and functional blocks and ensuring the creation of high-quality accounting information on the formation of environmental protection costs and their results.
\end{abstract}

\section{Introduction}

It is quite obvious today that any social and economic problems should be solved taking into account the requirements of the external environment.

It the same time, any desire to get only economic profit from the activity, without taking into account the possible environmental consequences, leads to rather harmful effects on the natural environment and has a negative impact on human health.

Seeing that construction activity is heavily tied to human intervention into the natural environment, it is necessary to make reasonable architectural and construction and other solutions important for the preservation of ecological balance in nature and its protection.

All persons which are directly involved in construction have to be involved in process of protection of the external environment. The designer should develop the project of future construction based on the current ecological legislation; the customer is obliged to approve the specification for the designer, also obtaining necessary permissions for construction belongs to its duties; the contractor is obliged to perform all construction works based on the project documentation and statutory requirements in the sphere of protection of the natural environment [1-10].

In case of any harm to the natural environment, the general contractor must completely compensate for the damage caused.

In fine, it should be noted that construction companies have to perform a number of activities aimed at restoring and preserving the natural environment. As a consequence of this, construction companies incur significant costs in cases of repairing the damage, restoring the natural environment. Therefore, competent management of environmental costs

\footnotetext{
*Corresponding author:22969@mail.ru
} 
plays an important role in the formation of the financial results of the company.

Government agencies regulate the protection of the natural environment, and obligate manufacturing companies to be fully responsible for the environmental cleanness of their production by compensating of damage caused from their own funds.

\section{Methods and materials}

The dialectical method, which is proposed as a general approach to the knowledge of the subject in question, serves as the methodological basis. As a result of this study, the scientific apparatus of management accounting, standard methods of analysis and evaluation of various data were applied. We also used general scientific methods of knowledge, such as logical generalization, systems approach, economic and legal analysis, and various hypotheses.

\section{Results}

Traditional methods of competent environmental management are primarily focused on the companies' passive compliance with environmental requirements, as well as on possible responses to the current pressure of all external parties. [3, 4, 7, 8].

Currently, it is required an effective environmental strategy. At the same time, a significant role in this strategy should be given to the costs associated with the implementation of environmental measures $[4,6]$.

The negative consequences of environmental and economic risks that are associated with any violations are shown in Figure 1.

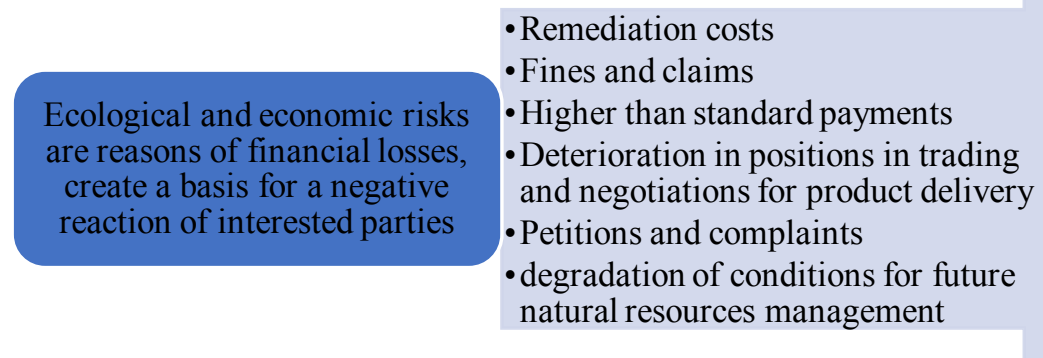

Fig. 1. Negative consequences of the implementation of environmental and economic risks associated with violations of environmental legislation

Let's understand in detail what the environmental costs are. A number of authors noted that they under environmental costs understand the costs that have been spent on environmental activities, the main purpose of which was to prevent possible violations of the environmental nature.

Environmental actions are understood as various activities that are aimed at the preservation of natural resources and systems, their quality and quantity [1,5].

After analyzing the information on this issue, we propose the following definition:

The cost of environmental activities is the use of various resources (labour, cost and material); aimed at eliminating the negative impact of a number of technological processes on the environment and on the livelihoods of the population, as well as on the company's environmental policy.

In addition, we also identified the main areas of formation of costs that are associated 
with environmental activities, based on which the main areas of cost management, their systematization and creation of an analytical accounting mechanism (Fig. 2).

\begin{tabular}{|c|c|c|}
\hline $\begin{array}{c}\text { Company standards } \\
\text { Training system }\end{array}$ & $\begin{array}{c}\text { Information } \\
\text { support }\end{array}$ & $\begin{array}{c}\text { Environmental } \\
\text { rating for } \\
\text { companies }\end{array}$ \\
\hline $\begin{array}{c}\text { Mechanisms } \\
\text { (financial, economic) }\end{array}$ & $\begin{array}{c}\text { Effective company activity directed at } \\
\text { environmental protection }\end{array}$ & $\begin{array}{c}\text { Optimal existing } \\
\text { technologies }\end{array}$ \\
\hline $\begin{array}{c}\text { Qualified specialists: } \\
\text { legal advice; } \\
\text { environmental } \\
\text { management and } \\
\text { audit }\end{array}$ & $\begin{array}{c}\text { The thorough analysis of the experience } \\
\text { of introducing modern environmental } \\
\text { protection equipment and efficient } \\
\text { technologies }\end{array}$ & $\begin{array}{c}\text { The regulatory and } \\
\text { legal base }\end{array}$ \\
\hline
\end{tabular}

Fig. 2. Directions of cost associated with environmental activities

There are certain features inherent in the costs of environmental protection measures that are allocated based on an economic production characteristic: they are not embodied in the released goods, so an increase in such costs does not lead to production growth, and their absence does not cause a decrease in output. Therefore, these costs are rationalized.

There are certain features inherent in the costs of environmental protection measures that are allocated based on an economic production characteristic: they are not embodied in the released goods, so an increase in such costs does not lead to production growth, and their absence does not cause a decrease in output. Therefore, these costs are rationalized $[2,5]$.

However, just like other costs, environmental costs need to be carried out at the enterprise valuation and quantification, analysis and tracking of their movement and condition, which is not possible without a systematic and full account of these costs (Fig. 3) [10].
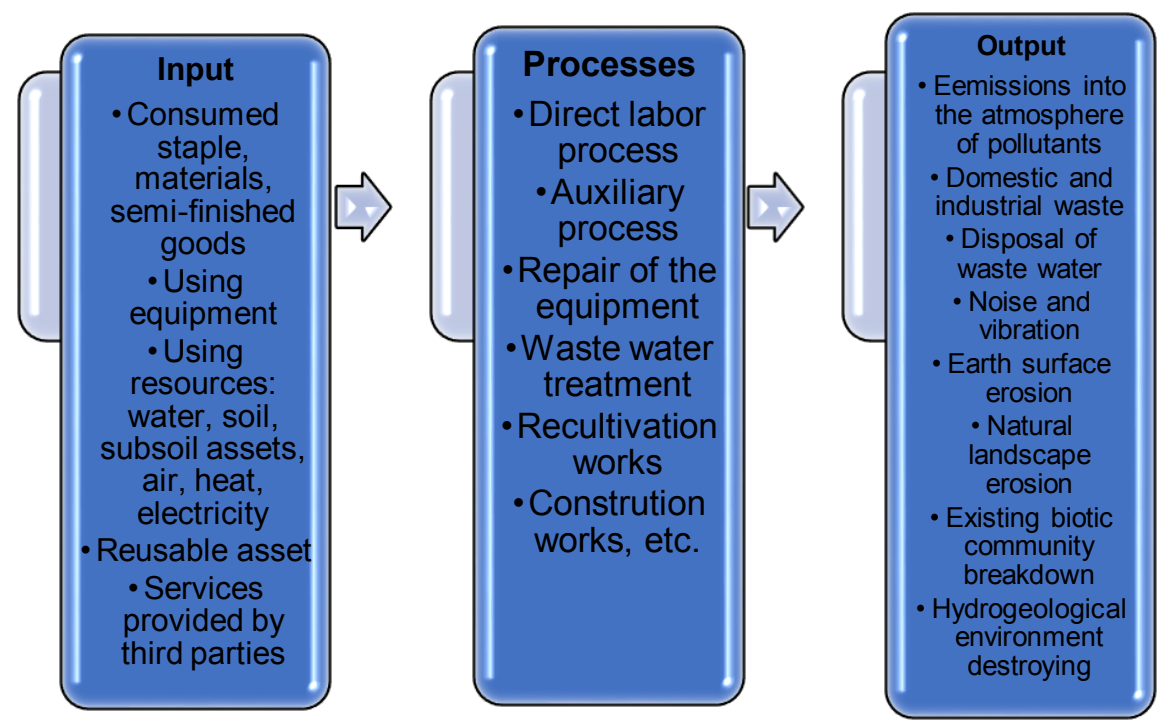

Fig. 3. Process approach for identification of ecological aspects 
In this regard, it is advisable to develop a mechanism that allows you to manage costs in management accounting and will include all the conditions required for accounting: accuracy, efficiency and quality of accounting data.

According to this interpretation relevance of using the cost accounting of a construction organization is evident within the categories of "business process-function" proposed by us when, in connection with the intersection of functions and business processes in general, costs acquire certain functions.

This ensures the creation of high-quality accounting information on the formation of environmental expenditures and their results.

For example, a construction organization can use:

A: business process: 1) production; 2) allocation of indirect costs; 3 ) management;

B: functions: 1) government regulation of business; 2) legal support of business process; 3) environmental protection measures; 4) greening construction; 5) energy audit.

The formation of functional blocks on the example of the business process "Production" can have the following options:

- production - legal support;

- production - government regulation;

- production - environmental protection measures.

- production - greening construction;

- production - energy internal and external audit.

If it is necessary, it is also possible to detail key features by their spheres and specific categories.

We believe it is quite reasonable to divide the costs of environmental focus into two functional groups:

1) greening construction, that means ecologic performance evaluation. Greening construction acts as a tool to enable ecologic performance evaluation and formulate an optimal environmental policy in the company evaluation. Ecological certificate. Allows you to select the priority of financial investments (optimal investment programs);

2) costs associated with environmental measures that are allocated to the implementation of environmental actions (limiting the number of discharges and emissions of wastes, standardization of MPC of various harmful substances, limiting the amount of disposal of industrial waste, the level of MPC of discharges and emissions of harmful substances). Construction companies should hold such measures at least 1 time per year.

Table 1 shows the options for functionalities on the example of environmental capital expenditures.

Table 1. An example of a variant of the functionality of environmental capital expenditures

\begin{tabular}{|c|c|c|}
\hline Cost functions & Cost name & Analytics \\
\hline $\begin{array}{c}\text { Creation and regulation of the cost } \\
\text { of basic environmental protection } \\
\text { tools (construction, acquisition, } \\
\text { leasing, exchange or gratuitous } \\
\text { purchase) }\end{array}$ & $\begin{array}{c}\text { Additional and main costs aimed at } \\
\text { increasing the value of fixed assets } \\
\text { of an environmental nature } \\
\text { (measuring instruments, cleaning } \\
\text { equipment, dust trapping systems, } \\
\text { specialized transport vehicles) } \\
\text { Expenses for capital repairs of } \\
\text { environmental protection equipment }\end{array}$ & $\begin{array}{c}\text { Wastewater treatment costs } \\
\text { Disposal costs of various solid } \\
\text { waste }\end{array}$ \\
\hline $\begin{array}{c}\text { Creation and regulation of the value } \\
\text { of assets (intangible) for the } \\
\text { purchase of patents and copyrights }\end{array}$ & $\begin{array}{c}\text { Additional and main costs aimed at } \\
\text { increasing the value of intangible } \\
\text { assets (environmental) }\end{array}$ & $\begin{array}{c}\text { Fee for environmental } \\
\text { expertise }\end{array}$ \\
\hline
\end{tabular}




\begin{tabular}{|c|c|c|}
\hline $\begin{array}{c}\text { Creation and regulation of the cost } \\
\text { of design, research and } \\
\text { technological work (various bench } \\
\text { tests, pilot production, cost of } \\
\text { experimental activities) }\end{array}$ & $\begin{array}{c}\text { Expenses for the improvement of } \\
\text { environmental facilities, } \\
\text { modification of technological } \\
\text { processes, as well as the } \\
\text { introduction of environmental-safe } \\
\text { equipment in the company }\end{array}$ & $\begin{array}{c}\text { Improving environmental } \\
\text { property } \\
\text { Introduction and development } \\
\text { of environmental technologies } \\
\text { Creation of environmental } \\
\text { goods }\end{array}$ \\
\hline
\end{tabular}

With regard to management accounting view, internal processes in an organization are capable of being fixed to the effect of any one of the categories mentioned above (the function of the process is revealed). In a similar context, the accounting of all environmental expenditures at an enterprise can be carried out according to a structural decomposition (if the activity of the structural unit is taken as a process).

Thus, in the context of accounting and analytical provision, the mechanism for creating management information reflects the main property of costs - to perform the generalized functions of processes and costs.

Similarly, as part of the bulk of the (internal) process aimed at achieving any effects from this category, there are costs that are aimed at acquiring the effects of all cross-categories. Taking into account the intersection of business process and functions, the costs are allocated to separate functional blocks (Table 2).

Table 2. An example of the formation of functional blocks for the business process with the function "Environmental protection measures"

\begin{tabular}{|c|c|c|c|}
\hline $\begin{array}{l}\text { Business } \\
\text { process }\end{array}$ & Functional block & Cost function & $\begin{array}{l}\text { Examples of costs associated } \\
\text { with environmental activities }\end{array}$ \\
\hline Production & $\begin{array}{c}\text { Production - } \\
\text { environmental } \\
\text { protection measures }\end{array}$ & $\begin{array}{l}\text { An } \\
\text { environmentally } \\
\text { safe production } \\
\text { process }\end{array}$ & $\begin{array}{c}\text { Product certification } \\
\text { The introduction of new } \\
\text { production technologies } \\
\text { Training } \\
\end{array}$ \\
\hline Management & $\begin{array}{c}\text { Management - } \\
\text { environmental } \\
\text { protection measures }\end{array}$ & $\begin{array}{c}\text { Environmental } \\
\text { load on the } \\
\text { work of } \\
\text { management } \\
\text { departments }\end{array}$ & $\begin{array}{c}\text { Regulatory environmental } \\
\text { fees and charges } \\
\text { Financial penalties } \\
\text { Sanctions }\end{array}$ \\
\hline $\begin{array}{l}\text { Allocation } \\
\text { of indirect } \\
\text { costs }\end{array}$ & $\begin{array}{c}\text { Allocation of } \\
\text { indirect costs - } \\
\text { environmental } \\
\text { protection measures }\end{array}$ & $\begin{array}{c}\text { Ecological } \\
\text { support of } \\
\text { general business } \\
\text { process }\end{array}$ & $\begin{array}{c}\text { Environmental risk } \\
\text { insurance } \\
\text { Environmental audit } \\
\text { Payment of environmental } \\
\text { consulting services }\end{array}$ \\
\hline Management & $\begin{array}{c}\text { Production - } \\
\text { environmental } \\
\text { protection measures }\end{array}$ & $\begin{array}{l}\text { Organization } \\
\text { and } \\
\text { management of } \\
\text { environmental } \\
\text { policy } \\
\end{array}$ & $\begin{array}{l}\text { Costs for special purpose } \\
\text { production services } \\
\text { Contents of environmental } \\
\text { control services }\end{array}$ \\
\hline Management & $\begin{array}{c}\text { Allocation of } \\
\text { indirect costs - } \\
\text { environmental } \\
\text { protection measures }\end{array}$ & $\begin{array}{l}\text { Ecological and } \\
\text { legal support of } \\
\text { material and } \\
\text { technical } \\
\text { conditions for } \\
\text { the work of } \\
\text { auxiliary and } \\
\text { service } \\
\end{array}$ & $\begin{array}{l}\text { Cost of compliance with } \\
\text { boiler room safety standards } \\
\text { Maintenance of services for } \\
\text { the cleaning of the area from } \\
\text { industrial pollution }\end{array}$ \\
\hline
\end{tabular}




\begin{tabular}{|c|c|c|c|}
\hline & & departments & \\
\hline $\begin{array}{l}\text { Allocation } \\
\text { of indirect } \\
\text { costs }\end{array}$ & $\begin{array}{c}\text { Production - } \\
\text { environmental } \\
\text { protection measures }\end{array}$ & $\begin{array}{c}\text { Creation of an } \\
\text { environmental } \\
\text { legal base for } \\
\text { production } \\
\text { service }\end{array}$ & $\begin{array}{c}\text { Acquisition of } \\
\text { environmental property } \\
\text { R\&D on the development of } \\
\text { environmental technologies } \\
\text { Construction of health } \\
\text { centres }\end{array}$ \\
\hline
\end{tabular}

Thus, costs are identified by functional units and main processes.

\section{Discussions}

We believe that it is necessary to develop and approve local documentation (internal accounting standards of the company) in a separate accounting of environmental costs. For such standards, recommendations and guidelines developed by accounting professional organizations (non-profit) can serve as a quality base.

\section{Conclusion}

In conclusion, it should be noted that:

1. One of the main criteria for the effectiveness of the analytical accounting mechanism for a company today is the approximation of this provision to the existing management systems. Due to the result of the production and economic activity of the enterprise, it is necessary to take into account the possible environmental consequences when making a certain decision.

An improper organization, work and ill-conceived technologies entail enormous costs of materials and energy and lead to severe pollution of the natural environment.

In this context, the object of management accounting with primary informational importance is the costs of environmental protection, formed under the influence of threats from outside.

However, there are no scientifically valid methods for identifying these costs and methodological provisions for their accounting and control.

2. At the end of we developed a methodical approach to determine the typology of environmental protection costs, based on the relationship between the categories of "business process-function".

3. The recommended methodology for the functional and process accounting of environmental protection costs fully complies with the established standards for the formation of effective systems, being accessible and useful for making and considering various kinds of management decisions that are aimed at the economic and purposeful use of finance in the environmental protection work of companies.

4. The proposed methodology of accounting for environmental expenditures in its entirety will make it possible to revise approaches to the method of tracking data that are directly related to an increase in the parameters of the work of construction corporations; to establish the relationship between all target values, critical areas of activity, required expenditures, as well as expectations from management decision making; Significantly improve the processes of formation of the company's financial sustainability strategy under constant competition.

\section{References}

1. E. Yu. Voronova, Upravlencheskyu uchet (in Russian) (Yurayt, Moscow, 2016). 
2. L. N. Gerasimova, Formirovanie sistemi upravlencheskogo ucheta v stroitelnikh organizastiakh. Upravlencheskyu uchet (in Russian) 9 pp. 4-8. (2018).

3. M. D. Ivanova, Voprosy ucheta prirodookhrannikh zatrat I kalkulirovaniyz sebestoimosti produktsii s uchetom ee ekologicheskogo sooivetstvia. Mezhdunarodniy upravlencheskyu uchet (in Russian), 19 (2015).

4. A. V. Mandryukov, Okhrana okruzhauchei sredy pri vipolnenii stroitelnikh rabot// Stroitelstvo: bukhgalterskiy uchet I nalogooblozhenie (in Russian), 1 (2017)

5. A. A. Mitskevich, Upralenie zatratami i pribil'yu (in Russian). (OLMA-PRESS Invest, Moscow, 2017).

6. L. V. Chkhutiashvili, Ecologicheskiy audit: problemy i resheniya (in Russian), 1 (Auditor, 2016).

7. N. Ghodrati, Yiu T. Wing, S. Wilkinson, M. Shahbazpour, Role of Management Strategies in Improving Labor Productivity in General Construction Projects in New Zealand: Managerial Perspective. Journal of Management in Engineering, 34, iss. 6. (2018) URL: https://doi.org/10.1061/(ASCE)ME.1943-5479.0000641.

8. S. H. Iranmanesh, M. Shakhsi-Niaei, M. A. D. Yazdi, A Decision Support System for Stakeholder Management During Different Project Phases Considering Stakeholders' Personality Types and Available Resources (The Case of Behsama Web-Based Information System). Journal of Information Technology Management, 9, iss. 4, pp. 679 - 700 (2018)

9. M. Pilkiene, R. Alonderiene, A. Chmieliauskas, S. Simkonis, R. Muller, The Governance of Horizontal Leadership in Projects. International Journal of Project Management, 36, iss. 7, pp. 913 - 924 (2018) URL: https://doi.org/10.1016/j.ijproman.2018.06.002.

10. Xu Xiaoxiao, Wang Jiayuan, Zhengdao Li Clyde, Huang Wenke, Xia Nini, Schedule Risk Analysis of Infrastructure Projects: A Hybrid Dynamic Approach. Automation in Construction, 95, pp. 20 - 34 (2018) URL: https://doi.org/10.1016/j.autcon.2018.07.026. 